\title{
PENERAPAN STARTEGI ACTIVE LEARNING BERBASIS PROBLEM SOLVING UNTUK MENINGKATKAN AKTIVITAS DAN HASIL BELAJAR SISWA KELAS V DI SDN NAGA NURI SEMESTER I TAHUN PELAJARAN 2018/2019
}

\author{
Ibrahim \\ SDN Naga Nuri \\ ibrahimnaganuri@gmail.com
}

\begin{abstract}
ABSTRAK
Rendahnya hasil belajar siswa tersebut disebabkan oleh beberapa faktor, diantaranya adalah kurangnya aktivitas siswa dalam mengikuti pembelajaran yaitu pada saat proses belajar berlangsung, sehingga siswa enggan untuk bertanya terhadap materi yang belum dipahami. Faktor lain yang menyebabkan adalah metode pembelajaran yang diterapkan dalam proses pembelajaran masih berpusat pada guru, sehingga siswa menjadi bosan, mengantuk, dan hanya mencatat saja, akhirnya siswa kurang aktif dalam proses pembelajaran. Sehingga mereka tidak terlatih berpikir kreatif dalam menemukan jawaban sendiri dalam pemecahan masalah PKn. Untuk mengantisipasi masalah di atas perlu dilakukan inovasi pembelajaran yang dapat membantu meningkatkan pemahaman dan penalaran siswa. Salah satu upaya yang dapat ditempuh dengan cara menerapkan strategi pembelajaran yang lebih efektif untuk pengajaran. Salah satu metode yang diperkenalkan pada dunia pendidika adalah metode pemecahan masalah (Problem Solving). Subyek dalam penelitian ini adalah siswa kelas V SDN Naga Nuri Tahun Pelajaran 2018/2019 dengan jumlah 18 siswa. Rancangan penelitian ini menggunakan rancangan penelitian tindakan kelas dengan dua siklus. Setiap siklus meliputi tahap perencanaan, pelaksanaan, pengamatan, dan refleksi.

Hasil penelitian ini disimpulkan bahwa metode pembelajaran problem solving dapat meningkatkan aktivitas dan hasil belajar siswa. Pembelajaran dengan metode problem solving memiliki dampak positif dalam meningkatkan hasil belajar siswa yang ditandai dengan peningkatan ketuntasan belajar siswa dalam setiap siklus, yaitu siklus I (38,89\%), siklus II (88,89\%). Penerapan metode problem solving mempunyai pengaruh positif, yaitu dapat meningkatkan aktivitas belajar siswa yang ditunjukan dengan hasil observasi per siklus menunjukkan peningkatan. Pada siklus I keaktifan siswa tergolong cukup aktif dengan persentase 55\%. Pada siklus II mengalami peningkatan yang tergolong sangat aktif dengan persentase $95 \%$. Pembelajaran dengan menggunakan model problem solving dapat digunakan guru untuk lebih memaksimalkan kegiatan pembelajaran, siswa tidak bosan dan pemahaman siswa akan tertanam melalui penelitian yang mereka lakukan. Bagi siswa dengan karakteristik yang aktif, mandiri, serta percaya diri atau bagi siswa yang kurang aktif, kurang percaya diri, belajar dapat menggunakan model problem solving, seperti pada mata pelajaran PKn.
\end{abstract}

Kata kunci: Hasil Belajar, Aktivitas Belajar, metode problem solving

\section{PENDAHULUAN}

Pendidikan adalah proses perubahan sikap tingkah laku seseorang atau kelompok orang dalam usaha mendewasakan manusia melalui upaya pengajaran penelitian. Pendidikan juga dapat diartikan sebagai perbuatan untuk memperoleh pengetahuan (Muhabbin dan Aini, 2004:125). Lebih luas lagi pendidikan merupakan proses dengan metode-metode tertentu sehingga orang akan memperoleh pengetahuan, pemahaman, dan cara bertingkah laku sesuai dengan kebutuhan. Mengingat peran pendidikan tersebut maka sudah seharusnya aspek ini menjadi perhatian pemerintah dalam rangka meningkatkan sumber daya masyarakat Indonesia yang berkualitas. PKn sebagai salah satu mata pelajaran di sekolah dinilai cukup memegang peranan penting dalam membentuk siswa menjadi berkualitas, karena PKn merupakan suatu sarana berpikir untuk mengkaji sesuatu secara logis dan sistematis. Karena itu, maka perlu 
adanya peningkatan mutu pendidikan PKn. Salah satu hal yang harus diperhatikan adalah peningkatan aktivitas prestasi belajar PKn siswa di sekolah.

Dalam pembelajaran di sekolah, PKn merupakan salah satu mata pelajaran yang masih dianggap sulit dipahami oleh siswa. Oleh karena itu dalam proses pembelajaran PKn diperlukan suatu metode mengajar yang bervariasi. Artinya dalam penggunaan metode mengajar tidak harus sama untuk semua pokok bahasan, sebab dapat terjadi bahwa suatu metode mengajar tertentu cocok untuk satu pokok bahasan tetapi tidak untuk pokok bahasan yang lain. Menurut Djamarah (2007:23), Penggunaan satu metode lebih cenderung menghasilkan kegiatan belajar mengajar yang membosankan bagi siswa, cara mengajarpun tampak kaku sehingga kurang bergairah mengajar, kejenuhan dan kemalasan menyelimuti kegiatan belajar siswa. Salah satu metode yang biasa digunakan yaitu metode yang belum mengaktifkan belajar siswa (ceramah) karena penerapan metode ini pengajarannya lebih berpusat pada guru, siswa hanya mendengarkan, menulis, dan menghafal materi yang diajarkan dan mengajarkan soal secara individu dan kelompok. Mereka jarang mengajukan pertanyaan pada hal yang belum mereka pahami. Kondisi seperti ini terjadi pula pada kelas V SDN Naga Nuri. Masalah yang dihadapi siswa dalam proses belajar mengajar yaitu kesulitan siswa dalam memahami materi yang diajarkan guru dengan menggunakan metode yang belum mengaktifkan siswa secara penuh sehingga menyebabkan aktivitas dan prestasi belajar siswa tidak maksimal.

Berdasarkan hasil observasi awal yang dilaksanakan di SDN Naga Nuri, diperoleh data berupa nilai hasil belajar kelas V. Dimana dari nilai tersebut dihitung nilai rata-rata kelas dan persentase ketuntasan belajar siswa secara klasikal. Ketuntasan klasikal yang diperoleh siswa kelas V sebesar 50\%, siswa masih belum mencapai Kriteria Ketuntasan Minimal (KKM) yaitu sebesar 75\%. Rendahnya hasil belajar siswa tersebut disebabkan oleh beberapa faktor, diantaranya adalah kurangnya aktivitas siswa dalam mengikuti pembelajaran yaitu pada saat proses belajar berlangsung, sehingga siswa enggan untuk bertanya terhadap materi yang belum dipahami. Faktor lain yang menyebabkan adalah metode pembelajaran yang diterapkan dalam proses pembelajaran masih berpusat pada guru, sehingga siswa menjadi bosan, mengantuk, dan hanya mencatat saja, akhirnya siswa kurang aktif dalam proses pembelajaran. Sehingga mereka tidak terlatih berpikir kreatif dalam menemukan jawaban sendiri dalam pemecahan masalah Matematika.

Untuk mengantisipasi masalah di atas perlu dilakukan inovasi pembelajaran yang dapat membantu meningkatkan pemahaman dan penalaran siswa. Salah satu upaya yang dapat 
ditempuh dengan cara menerapkan strategi pembelajaran yang lebih efektif untuk pengajaran. Salah satu metode yang diperkenalkan pada dunia pendidikan adalah metode pemecahan masalah (Problem Solving). Metode pemecahan masalah adalah suatu cara yang menyajikan pelajaran dengan mendorong peserta didik untuk mencari dan memecahkan suatu masalah/persoalan dalam rangka pencapaian tujuan pengajaran. Metode ini diciptakan oleh seorang ahli didik berkebangsaan Amerika yang bernama Jhon Dewey. Metode ini dinamakan problem method. Sedangkan Crow \& Crow dalam bukunya Human Development and Learning, mengemukakan nama metode ini dengan Problem solving Method (Ibid , 2002:12). Menurut Sudjana (2000:144), metode Problem solving (Pemecahan Masalah) bukan hanya sekedar metode mengajar tetapi juga merupakan suatu metode berpikir, sebab dalam metode problem solving dapat menggunakan metode-metode lainnya dimulai dengan mencari data sampai kepada menarik kesimpulan.

Pengunaan metode problem solving dalam pembelajaran mengikuti langkah-langkah: (1) Adanya masalah yang jelas untuk dipecahkan, Masalah ini harus tumbuh dari siswa sesuai dengan taraf kemampuannya, (2) Mencari data atau keterangan yang dapat digunakan untuk memecahkan masalah tersebut. Misalnya, dengan jalan membaca buku-buku, meneliti, bertanya, berdiskusi, dan lain-lain, (3) Menetapkan jawaban sementara dari masalah-masalah tersebut. Dugaan jawaban ini tentu saja di dasarkan kepada data yang diperoleh, pada langkah kedua di atas, (4) Menguji kebenaran jawaban sementara tersebut. Dalam langkah ini siswa harus berusaha memecahkan masalah sehingga betul-betul yakin bahwa jawaban tersebut betul-betul cocok. Apakah sesuai dengan jawaban sementara atau sama sekali tidak sesuai. Untuk menguji kebenaran jawaban ini tentu saja diperlukan metode-metode lainnya seperti demonstrasi, tugas diskusi, dan lain-lain, (5) Menarik kesimpulan. Artinya siswa harus sampai kepada kesimpulan terakhir tentang jawaban masalah tadi.

Berdasarkan uraian di atas, maka peneliti tertarik untuk melakukan suatu penelitian yang berjudul : "Penerapan strategi Active Learning Berbasis Problem Solving untuk Meningkatkan Aktivitas dan Hasil Belajar Siswa Kelas V di SDN Naga Nuri Semester I Tahun Pelajaran 2018/2019. 


\section{METODE PENELITIAN}

Penelitian ini adalah Penelitian Tindakan Kelas (PTK) atau Classroom Action Research (CAR), yaitu penelitian tindakan yang dilakukan di kelas dengan tujuan memperbaiki mutu praktik pembelajaran. Pemilihan metode penelitian tindakan kelas karena mempertimbangkan: (1) masalah yang dihadapi adalah masalah yang timbul dalam proses pembelajaran, (2) tidak menganggu jalanya pembelajaran sesuai kompetensi yang diajarkan, (3) ingin melihat perkembangan sampai adanya peningkatan motivasi dan hasil belajar. Pada intinya PTK merupakan suatu penelitian yang akar permasalahannya muncul dikelas dan dirasakan langsung oleh guru yang bersangkutan sehingga sulit dibenarkan jika ada anggapan bahwa permasalahan dalam tindakan kelas diperoleh dari persepsi atau lamunan seorang peneliti (Arikunto, 2006). Dengan demikian penelitian tindakan kelas (Classroom Action Research) terkait dengan persoalan praktik pembelajaran sehari-hari yang dihadapi oleh guru. Dalam konteks pendidikan, PTK merupakan tindakan perbaikan guru dalam mengorganisasi pembelajaran di dalam kelas. Prosedur penelitian mengambil 4 langkah, yaitu: (1) perencanaan, (2) pelaksanaan, (3) observasi, dan (4) refleksi.

Penelitian ini dilaksanakan di SDN Naga Nuri, Subyek dalam penelitian ini adalah siswa kelas V yang berjumlah 18 siswa. Waktu pelaksanaan semester I Tahun Pelajaran 2018/2019. Faktor yang diteliti dalam penelitian ini adalah siswa: (1) Melihat aktivitas siswa dalam bertanya dan mengemukakan pendapat pada materi wilayah Negara Kesatuan Repubelik Indonesia yang telah disampaikan guru dengan metode Problem Solving, (2) Hasil belajar siswa setelah kegiatan pembelajaran yang berasal dari nilai tes pada setiap akhir siklus.

Penelitian ini direncanakan 2 siklus. Pada tiap siklus terdiri dari 4 tahapan, yaitu: 1) Perencanaan, 2) Pelaksanaan Tindakan, 3) Observasi, 4) Refleksi.

1. Perencanaan

Perencanaan merupakan perisiapan yang dilakukan sehubungan dengan pelaksanaan pembelajaran dengan metode Problem Solving untuk menyelesaikan masalah. Rencana kegiatan yang akan dilakukan pada tahap ini adalah:

a. Guru menjelaskan tujuan pembelajaran materi pelajaran

b. Guru membagi siswa menjadi 4 kelompok dengan anggota tiap kelompok 4 atau 5 anak dari jumlah peserta didik 18 anak.

c. Guru memanggil kelompok, kelompok memilih topik-topik yang telah disiapkan guru, terdapat tugas kelompok dalam topik yang dipilih. Setiap kelompok mengerjakan tugas kelompok pada lembar kerja kelompok, siswa saling membantu satu sama lain. 
d. Setelah selesai kelompok mempresentasikan hasil kerjanya secara bergiliran, siswa bersama guru membahas jawaban yang diperoleh dan disimpulkannya.

e. Kegiatan akhir pembelajaran melakukan evaluasi secara tertulis.

2. Pelaksanaan Tindakan dan Pengamatan

a) Pendahuluan

1) Menyiapkan Rencana Pelaksanaan Pembelajaran (RPP)

2) Menyiapkan materi PKn tentang Wilayah Negara Kesatuan Repubelik Indonesia yang terangkum dalam modul pembelajaran

3) Membuat instrument penelitian

4) Melakukan pembagian kelompok

5) Presentasi kelompok

b) Inti

Di dalam kelas siswa diharapkan dapat mengikuti proses pembelajaran dengan baik.

1) Mendengarkan saat guru sedang menerangkan materi pembelajaran

2) Menanyakan apa yang belum paham dari materi pelajaran yang disampaikan oleh guru.

3) Melaksanakan atau mengerjakan tugas yang diberikan oleh guru dengan penuh rasa tanggung jawab, cermat, dan tepat.

c) Penutup

1) Guru dengan siswa mengadakan refleksi terhadap proses dan hasil belajar

2) Guru memberi kesempatan siswa untuk bertanya. Apabila siswa merasa kurang paham atas materi yang disampaikan.

Pelaksanaan tindakan merupakan suatu kegiatan dilaksanakannya tahapan pembelajaran yang telah direncanakan. Dalam hal ini sesuai dengan Rencana Pelaksanaan Pembelajaran (RPP) yang telah disiapkan.

3. Observasi

Mencatat hasil pengamatan pada catatan lapangan dan lembar observasi. Tindak lanjutnya melakukan diskusi antara peneliti dengan teman sejawat sebagai observer. Pada saat proses pengamatan, hal-hal yang dilakukan yakni:

a) Saat pembelajaran dengan metode Problem Solving maka harus diobservasi kegiatan siswa dan guru dalam proses pembelajaran.

b) Melakukan penilaian hasil dan membuat laporan hasil temuan.

c) Pengumpulan lembar kegiatan siswa dan hasil belajar.

4. Refleksi 
a) Mengidentifikasi kesulitan dan hambatan pelaksanaan setiap siklus.

b) Menganalisis hasil pengamatan lembar observasi, catatan lapangan dan hasil tes kemudian dikaji dan refleksi untuk menyempurnakan tindakan selanjutnya.

Instrument yang digunakan dalam penelitian ini terdiri dari: (1) Rencana Pelaksanaan Pembelajaran (RPP), (2) Tes Evaluasi, (3) Lembar Kerja Ssiswa (LKS), (4) Validasis Tes, (5) Reliabilitas dan daya pembeda dan (6) Lembar Observasi. Sedangkan Metode pengumpul data di gunaka: (1) metode tes, (2) Metode Observasi, dan (3) metode dokumentasi.

Analisis data adalah menganalisis tingkat keberhasilan atau persentase keberhasilan setelah proses pembelajaran setiap siklus, dilakukan dengan cara memberi evaluasi berupa soal tes tertulis pada setiap akhir sklus. Adapun indikator yang akan dilihat dalam penelitian ini adalah : (1) Hasil belajar siswa dikatakan meningkat apabila tercapainya ketuntasan belajar secara klasikal yaitu $\geq 75 \%$ dan siswa memperoleh nilai ketuntasan individual $\geq 73$, (2) Aktivitas guru dan siswa dikatakan meningkat apabila terjadinya peningkatan skor setiap siklusnya.

\section{HASIL DAN PEMBAHASAN}

Penelitian pada materi Wilayah Negara Kesatuan Repubelik Indonesia dengan menerapkan metode Problem Solving pada siswa kelas V SDN Naga Nuri Tahun Pelajaran 2018/2019. Dalam penelitian tindakan kelas ini peneliti bertindak sebagai guru sedangkan observernya adalah guru kelas V SDN Naga Nuri. peneliti dilaksanakan dalam dua siklus, yaitu siklus I dan II. Kehadiran peneliti sebagai guru di kelas sebagai pengajar tetap dan dilakukan seperti biasa, sehingga siswa tidak tahu kalau diteliti. Dengan cara ini diharapkan didapatkan data yang seobjektif mungkin demi kevalidan data yang diperlukan. Setiap siklus terdiri dari perencanaan, pelaksanaan, pengamatan dan refleksi. Hasil penelitian ini terdiri dari hasil tes dan non tes. Hasil tes didapatkan setelah menerapkan metode Problem Solving sedangkan hasil non tes didapatkan dari data hasil observasi aktivitas siswa.

Hasil belajar PKn siswa kelas V SD Negeri Naga Nuri Semester I Tahun Pelajaran 2018/2019 sebelum diadakan penelitian hampir setengah dari jumlah siswa kelas V belum tuntas KKM ( $\geq 75 \%$ ), yaitu 50\%. Hal ini dikarenakan guru masih cenderung menggunakan ceramah dalam proses pembelajaran. Jadi guru lebih aktif sedangkan siswanya pasif dalam proses pembelajan yang berlangsung. Sehingga siswa tidak secara optimal menyerap materi pelajaran yang disampaikan, siswa akan merasa jenuh dan bosan. Sehingga hasil belajar siswa dalam pelajaran PKn dengan pokok bahasan Wilayah Negara Kesatuan Repubelik Indonesia 
hasilnya rendah. Penelitian tindakan kelas ini menggunakan metode Problem Solving diharapkan dapat meningkatkan hasil belajar siswa.

Hasil pengamatan siklus I dicatat dalam lembar observasi yang telah dipersiapkan. Pengamatan siklus I diperoleh 55\% siswa cukup aktif dalam pembelajaran dengan menggunakan metode metode Problem Solving. Berdasarkan hasil pengamatan pada siklus I siswa masih kurang maksimal dalam proses pembelajaran. Adapun yang menjadi kendalanya sebagai berikut: (1) Hasil observasi aktivitas belajar siswa mencapai 55\%. Hal ini menunjukkan siswa masih kurang maksimal dalam pembelajaran, (2) Siswa belum memahami dengan metode Problem Solving, (3) Siswa masih kurang antusias dalam proses pembelajaran

Hasil evaluasi pembelajaran pembelajaran pada siklus I dengan metode Problem Solving mencapai 38,89\% dari 18 siswa hanya 7 siswa yang nilai hasil belajarnya di atas 73 . Hasil tersebut menunjukkan bahwa pada siklus pertama secara klasikal siswa belum tuntas belajar lebih kecil dari persentase ketuntasan yang dikehendaki yaitu sebesar $75 \%$.

Hasil pengamatan siklus II dicatat dalam lembar observasi yang telah dipersiapkan. Pengamatan siklus II diperoleh hasil $95 \%$ siswa aktif dalam pembelajaran dengan metode Problem Solving. Berdasarkan hasil pengamatan pada siklus II baik guru maupun siswa sudah mengalami peningkatan dalam proses pembelajaran. Adapun hasil persentasenya sebagai berikut: (1) Hasil observasi aktivitas belajar siswa mencapai 95\%. Hal ini menunjukkan siswa sudah mulai aktif dan maksimal dalam pembelajaran, (2) Kemampuan guru dalam menerapkan metode Problem Solving sangat baik, (3) Siswa sangat antusias dalam proses pembelajaran dengan metode Problem Solving, (3) Siswa semaki baik dalam bertanya, dan mengemukakan pendapatnya.

Hasil evaluasi pembelajaran pembelajaran pada siklus II dengan metode Problem Solving mengalami peningkatan dengan persentase ketuntasan klasikal mencapai mencapai 88,89\% dari 18 siswa 16 diantaranya mendapatkan skor hasil belajar di atas 73 . Hasil tersebut menunjukkan bahwa pada siklus II ini secara klasikal siswa sudah tuntas dari persentase ketuntasan yang dikehendaki yaitu sebesar $75 \%$. Adanya peningkatan hasil belajar siswa ini karena siswa sudah mulai akrab dan menemuan keasyikan dengan metode Problem Solving. Disamping itu kemampuan guru dalam mengelola proses belajar mengajar dalam metode ini juga semakin meningkat sehingga proses belajar-mengajar semakin efektif.

Berdasarkan tes hasil belajar yang dilakukan tiap pembelajaran atau persiklusnya diketahui bahwa siswa semakin aktif pada pertemuan berikutnya meskipun pada pertemuan pertama hasilnya kurang dari harapan. Hal ini ditandai dengan semakin meningkatnya jumlah 
ketuntasan. Pada siklus I persentase ketuntasan 38,89\%. Pada siklus II persentase ketuntasan $88,89 \%$. Pada tahap ini siswa sudah aktif dalam proses belajar mengajar dan siswa sudah memahami materi yang diajarkan pada materi sebelumnya.

Berdasarkan hasil observasi aktivitas belajar siswa menunjukkan peningkatan. Pada siklus I keaktifan siswa tergolong cukup aktif dengan persentase 55\% karena siswa masih terpengaruh terhadap situasi di luar kelas dan tidak berusaha menjawab pertanyaan yang diberikan oleh guru. Sedangkan pada siklus II mengalami peningkatan yang tergolong sangat aktif dengan persentase $95 \%$ dikarenakan siswa telah memperbaiki kesalahan pada siklus I diantaranya tidak terpengaruh terhadap situasi di luar kelas dan berusaha menjawab pertanyaan yang diberikan oleh guru serta bertanya apabila mengalami kesulitan.

Peningkatan hasil dan aktivitas belajar merupakan tolak ukur untuk mengetahui tingkat keberhasilan siswa dalam proses belajar mengajar. Proses belajar mengajar dikatakan baik, bila proses tersebut dapat membangkitkan kegiatan belajar yang efektif. Jika dilihat dari hasil belajar yang diperoleh siswa persiklus mengalami peningkatan. Peningkatan hasil belajar dikarenakan adanya peningkatan aktivitas guru dan siswa pada siklus I dan II, artinya proses pembelajaran dengan metode Problem Solving mengalami perbaikan.

Dengan demikian, bahwa penerapan model pembelajaran Problem Solving dapat mempermudah guru dalam menyampaikan informasi atau pengetahuan, tahap demi tahap dan dapat mengaitkan materi dengan situasi dunia nyata siswa dan mendorong siswa membuat hubungan antara pengetahuan dengan penerapan kehidupan siswa sehari-hari sehingga siswa akan merasakan pembelajaran sangat bermanfaat dan menciptakan pembelajaran menjadi lebih menarik atau menyenangkan karena siswa akan belajar melalui pengalaman bukan menghapal, dan berdampak terhadap meningkatkan aktivitas berkarya dan hasil belajar PKn.

Metode pemecahan masalah adalah suatu cara yang menyajikan pelajaran dengan mendorong peserta didik untuk mencari dan memecahkan suatu masalah/persoalan dalam rangka pencapaian tujuan pengajaran. Metode ini diciptakan oleh seorang ahli didik berkebangsaan Amerika yang bernama Jhon Dewey. Metode ini dinamakan problem method. Sedangkan Crow dan Crow dalam bukunya Human Development and Learning, mengemukakan nama metode ini dengan Problem solving Method (Ibid , 2002:12). Menurut Sudjana (2000:144), metode Problem solving (Pemecahan Masalah) bukan hanya sekedar metode mengajar tetapi juga merupakan suatu metode berpikir, sebab dalam metode problem solving dapat menggunakan metode-metode lainnya dimulai dengan mencari data sampai kepada menarik kesimpulan. 


\section{KESIMPULAN}

Hasil kegiatan pembelajaran yang telah dilakukan selama 2 siklus, dan berdasarkan seluruh pembahasan serta analisis yang telah dilakukan dapat disimpulkan sebagai berikut: (1) Pembelajaran dengan metode problem solving memiliki dampak positif dalam meningkatkan hasil belajar siswa yang ditandai dengan peningkatan ketuntasan belajar siswa dalam setiap siklus, yaitu siklus I $(38,89 \%)$, siklus II $(88,89 \%)$, (2) Penerapan metode problem solving mempunyai pengaruh positif, yaitu dapat meningkatkan aktivitas belajar siswa yang ditunjukan dengan hasil observasi per siklus menunjukkan peningkatan. Pada siklus I keaktifan siswa tergolong cukup aktif dengan persentase 55\%. Pada siklus II mengalami peningkatan yang tergolong sangat aktif dengan persentase $95 \%$.

Hasil penelitian yang diperoleh dari uraian sebelumnya agar proses belajar mengajar agama islam lebih efektif dan lebih memberikan hasil yang optimal bagi siswa, maka disampaikan saran sebagai berikut: (1) Pembelajaran dengan menggunakan model problem solving dapat digunakan guru untuk lebih memaksimalkan kegiatan pembelajaran, siswa tidak bosan dan pemahaman siswa akan tertanam melalui penelitian yang mereka lakukan, (2) Bagi siswa dengan karakteristik yang aktif, mandiri, serta percaya diri atau bagi siswa yang kurang aktif, kurang percaya diri, belajar dapat menggunakan problem solving, seperti pada mata pelajaran PKn. (3) Pada akhir kegiatan pembelajaran, sebaiknya guru melakukan refleksi untuk mengevaluasi kekurangan dalam kegiatan pembelajaran yang telah dilakukan

\section{DAFTAR PUSTAKA}

Anni. 2009. Psikologi Belajar. Semarang. UPT MKK UNNES

Aqib, 2007. Melaksanakan Penelitian Tindakan Kelas (PTK) Itu Mudah. Jakarta: Bumi Aksara. Arikunto. S. 2006. Prosedur Penilitian Suatu Pendekatan Praktek. Jakarta:Renika Cipta.

Faresnawati, 2006. Konsep dan Makna Pembelajaran.Bandung : Alfabeta

Hanafiah, 2009. Teknik Pembelajaran Bahasa dan Sastra. Surabaya: SIC

Pribadi, 2009. Metode dan Teknik Mengajar. Jakarta. Bumi Aksara

Sabri. 2007. Proses Belajar Mengajar. Jakarta. Rineka Cipta

Sanjaya, W. 2007. Strategi Pembelajaran. Jakarta: Kencana.

Santyasa, I W. 2009. Materi Pendidikan dan Latihan Profesi Guru (PLPG); Modelmodel Pembelajaran Inovatif. Singaraja: Universitas Pendidikan Ganesha

Sardiman. 2011. Interaksi dan Motivasi Belajar Mengajar. Jakarata: PT RajaGrafindo Persada 
Slameto. 2010. Belajar dan Faktor-Faktor Yang mempengaruhinya. Jakarta: Rineka Cipta

Slavin, Robert E. 2009. Cooperative Learning Teori, Riset, dan Praktik. Bandung: Nusa Media

Soemanto,Wasty. 2007. Psikologi Pendidikan. Jakarta: Rineka Cipta

Sudjana. 2006. Keaktifan Siswa. Bandung. Alfabeta

Trianto. 2010. Mendesain Model Pembelajaran Inovatif-Progresif: Konsep, Landasan, dan Implementasinya pada Kurikulum Tingkat Satuan Pendidikan (KTSP). Jakarta: Kencana 